\title{
Article
}

\section{Examining Asian and European reactions within shock advertising}

Engelbart, Silke Maria, Jackson, Delia Anne and Smith, Simon Martin

Available at https://clok.uclan.ac.uk/22945/

Engelbart, Silke Maria orcid iconORCID: 0000-0002-3699-1286, Jackson, Delia Anne and Smith, Simon Martin (2017) Examining Asian and European reactions within shock advertising. Asian Journal of Business Research, 7 (2). pp. 37-56. ISSN 2463-4522

It is advisable to refer to the publisher's version if you intend to cite from the work. 10.14707/ajbr.170036

For more information about UCLan's research in this area go to http://www.uclan.ac.uk/researchgroups/ and search for <name of research Group>.

For information about Research generally at UCLan please go to http://www.uclan.ac.uk/research/

All outputs in CLoK are protected by Intellectual Property Rights law, including Copyright law. Copyright, IPR and Moral Rights for the works on this site are retained by the individual authors and/or other copyright owners. Terms and conditions for use of this material are defined in the policies page.

\section{CLoK}

Central Lancashire online Knowledge www.clok.uclan.ac.uk

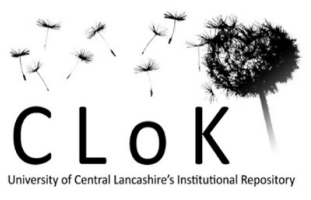




\title{
Examining Asian and European Reactions within Shock Advertising
}

\author{
Silke M. Engelbart \\ University of Central Lancashire, School of Language and Global Studies \\ Preston, England \\ Delia A. Jackson \\ University of Central Lancashire, School of Language and Global Studies \\ Preston, England \\ Simon M. Smith \\ University of Winchester, Winchester Business School, Winchester, England
}

\begin{abstract}
This paper seeks to establish whether subjects from different cultures, in this case from Europe (Germany, France, Spain and the United Kingdom (UK)) and Asia (China and Japan), react differently when exposed to the same shock advertising. This is of relevance to advertisers/ marketers who wish to target particular groups in a population as societies continue to evolve, change and become less homogenous. This paper examines the effects that gender and cultural identities have on different ethnic groups. The current study was carried out in the UK using 115 undergraduate university students from 6 countries. The participants were exposed to 7 adverts on safe driving from 4 countries. The aim of the study was to see if the participants would react differently to the degree of shock depending on the culture portrayed within the advert. Our findings highlight that there is a correlation between gender and the environment depicted within 3 of the adverts. Furthermore, significant differences between European and Asian participants were also found within 2 of those 3 adverts. The findings accentuate the importance of cultural content within shock advertising. Thus, advertisers/ marketers need to take great care when constructing and delivering messages to multi-cultural customer bases.
\end{abstract}

Keywords: Shock Advertising, Advertising, Marketing, Asia, Europe 


\section{Introduction}

Taboo topics such as shock tactics or sex appeal have been used in advertising for decades in order to cut through the clutter and grab attention. Research has highlighted that advertisements using shock tactics are more likely to be remembered than informative messages when it comes to public health advertising (Dahl et al. 2003). Indeed, shock tactics have been used by the not-for-profit as well as by the commercial sector. As Vagnoni (1999, p.30) pointed out as far back as 1999, using shock tactics had become commonplace not just in film and television series but also in advertising where practitioners were "pushing the limits of bad taste" in order to grab attention. Sometimes the aim is to make the advertising the subject of discussion and to raise awareness of the company; Benetton offering the classic example. Often, shock tactics are also used by charities and government bodies to focus attention on specific social problems, such as drink driving or child abuse, in an attempt to change behaviour (as illustrated by the children's charity Barnados). Diana Tickell, UK director of communications at Barnardo's, said "Shocking ads work for us as we need an effective way of capturing the viewer's attention amid a number of more expensive ads for more high-profile brands being broadcast" (Williams 2009, p.11).

Few researchers have studied the effect of culture on the reaction of viewers to shock or sex appeal adverts. Some of those who have investigated sex appeal adverts include Lass and Hart (2004), Paek and Nelson (2007), and Sawang (2010). Equally, there is a paucity of research in the area of shock advertising in the intercultural context although there are a few studies by Huhmann and Mott-Stenerson (2008), Dahl et al., (2003), Sierra et al., (2009) and Elias and Appiah (2010). This paper focuses on contributing towards the latter gap regarding studies of viewers within shock advertising. The current research is based on TV advertisements as Parry et al. (2013 p.119) had used billboard advertising as the basis of their research and recommended investigations into shock advertising in other media.

Parry et al. (2013) also used for-profit (FP) and not-for-profit (NFP) shock advertising in their study whereas this paper concentrates on the NFP sector as the majority of adverts which employ shock tactics are found in this sector. The degree of shock tactics applied, however, can vary according to the culture. Whilst France and the UK frequently use graphic images in shock advertising related to driving (e.g. the RSA's "the faster the speed, the bigger the mess" UK campaign), Germany uses a more subtle approach (as in their "Leben hat Vorrang" campaign from the 'bmvit' about wearing a seat belt). Though these cultures are geographically close, the execution of shock advertising is distinctly different. De Mooij (2010b, p.45) points out that "there are significant differences in communication behaviour between the North and the South of Europe", as well as between the Anglo-Saxon and the Asian world. She highlights the need for indigenous European and Latin-American communication theories to be developed and refers to current research to develop Asia-centric communication theories. Furthermore, as societies become less homogenous through, for example, immigration, study abroad, travel and the internet, it is perhaps pertinent to contemplate the impact of these varying shock tactics, which are often aimed at the indigenous population. This is particularly important for public health messages. If we take the UK as an example, recent immigration and cultural diversity figures show that in 2011 13\% of the UK population were born outside the UK. The top five countries immigrants have come from are (in order) India, Poland, Pakistan, Republic 
of Ireland and Germany (Office of National Statistics 2013). Consequently, practitioners need to be aware of the differing reactions to advertisements depending on the ethnic and cultural representations contained within them.

Thus, the primary research question is: how does shock advertising impact on multicultural audiences? This paper contributes to the paucity of research into how shock tactics affect cultures within an ever decreasing homogenous population. This is achieved using respondents from two Asian cultures (China and Japan) and four European cultures (France, Germany, Spain and the UK) to examine their experiences of shock adverts from various cultural backdrops. The results provide signposts and signals to inspire further research into targeting a culturally diverse customer base. The paper is structured as follows. The literature review will present a definition of shock advertising and how different societal norms affect the reactions to this type of advertising. Then, the methodology is introduced. Next, the findings are presented and their implications are discussed. The ethnicity, gender and cultural dimensions of the adverts, as well as of the participants in the study, are given particular consideration. Implications for practitioners and researchers, as well as limitations of the study and future research needs, are discussed at the end.

\section{Literature Review}

\section{Definition of Shock Advertising}

Researchers have established that the violation of societal norms is the defining characteristic of shock advertising, whether this takes the form of displaying vulgar body parts, death, violence or sex (Dahl et al. 2003; Huhmann and Mott-Stenerson 2008; Javed and Zeb 2011). Another area of research looks at the impact of potentially shocking product categories, coined the "unmentionables" by Wilson and West (1981). However, the current research is focusing on the shock impact of the images depicted and not the product or service itself. For the purposes of this study, the authors define shock advertising as an advertisement execution portraying disturbing images which are intended to adversely affect the viewer's emotions to such an extent that they think about the images for some time afterwards. This definition was used in the data collection where participants were asked to rate shock adverts shown to them.

\section{Cultural Dimension of Shock Advertising}

The violation of societal norms is the central tenet for shock advertising. However, societies have different societal values, customs or beliefs which may affect the execution of and reactions to shock advertising. A person's reaction to shock advertising may be influenced by cultural dimensions, such as those designated by Hofstede (1984), Hall (1976) and de Mooij (2010b). Furthermore, laws, customs, religions, beliefs, values, age and economic and political systems all play a role in shaping people's perceptions towards shock advertising.

Western societies are used to taboo topics such as shock tactics and this is also reflected to a larger or smaller extent in law enforcement. In the UK, the Advertising Standards Authority (ASA) have an unwritten rule that charitable organisations have more freedom when using shocking images, because of their not-for-profit status 
(Parry et al. 2013). In China, on the other hand, laws prevent the use of socially destabilizing content, which includes the violation of morals. Gao (2007) likens the Chinese advertising law of 1994 to legally institutionalised government censorship that therefore controls the use of disturbing images. Erevelles et al. (2002) argue that in Chinese society sexual references are seen as offensive and offer the example of the Chinese government banning a 'safe sex advert' after only one day because of a law forbidding the advertisement of sex-related products.

Fam and Waller (2003) state that collectivist societies, such as Taiwan and China, dislike any advertisements which undermine the harmony of their society. In a later study, which examines the perception of controversial product advertising in China using three generational cohorts, Fam et al. (2008) put forward a possible explanation that all three generations were offended by advertisements containing indecent language, hard-sell practices, violence and anti-social behaviour, because of traditional Confucian values and an innate sense of shame. Similarly, Prendergast et al. (2008) recommend that marketing practitioners should be careful when using offensive advertising in China as even in Hong Kong and Shanghai societies are conservative and adhere to Confucian principles and collectivist notions.

Studies which look at the correlation between the reactions to shock advertisements and culturally diverse participants are, as yet, relatively rare. Parry et al. (2013) highlight the lack of research carried out in the NFP sector which addresses individuals' responses to shock advertising. Whilst some research has been undertaken in the US to study offensive advertising and its effects on US consumers (Dahl et al. 2003; Huhmann and Mott-Stenerson 2008), and in recent years there has been a number of studies looking at reactions to offensive advertising in Asia, with particular emphasis on China (Erevelles et al. 2002; Fam and Waller 2003; Fam et al. 2008; Prendergast et al. 2008), very little research has been done regarding European consumers. This may be due in part to a long-standing practice, in particular in public service advertising, of using offensive advertisements to change public behaviour. However, there is a lack of European and indeed cross-cultural studies involving European and Asian consumers with regard to offensive advertising. One study by Chan et al. (2007) does look at Chinese and German consumers regarding offensive sexual appeal adverts and comes to the conclusion that, even though the Chinese perceived the adverts more negatively, the Germans also judged them in an unfavourable light. The difference in the participants' perception was explained mainly through the cultural dimension of high versus low context and collectivist versus individualistic dimensions (using established perspectives from Hofstede 1984). They found, for example, that information about the product needs to be put into context for Chinese consumers whereas German consumers require information to be objective and direct.

Some of the research into offensive advertising has involved subjects from a variety of European cultures. Notably, Lass and Hart (2004) examined different cultural values within three European countries within their study (UK, Germany and Italy) and found that Italians were more willing to accept sexual imagery in alcohol ads than German and British consumers. Paek and Nelson (2007) studied diverse cultures in their research by comparing the use of nudity in advertising in North and South America to that in China, Thailand and Korea. However, European countries were not included in this research. They found that the highest degree of female nudity in 
adverts was in Thailand, whilst China and South-Korea showed very little nudity in adverts. Brazil was found to employ much less nudity in adverts than expected. Nudity can be a taboo area in advertising in the same way that shock appeal is and we could expect that our research will come to similar conclusions regarding the reaction to shocking advertisements from our Chinese and Japanese participants.

Following on from the above, a further study by Sawang (2010) examined consumers' attitude towards sex in advertisements using one individualistic sample (White Americans), one collectivistic sample (Asian visitors to the US) and one acculturation sample (Asian immigrants to the US). Sawang concluded that Asian visitors to the US were less able to accept sexual content in advertising than the other groups. A study by Dahl et al. (2003) compares the effectiveness of shock advertising to that of fear and information as an advertising tool. They conclude that shocking content has many positive effects on participants, e.g. making the adverts more memorable, noticeable and influences positive behaviour. Although the study was undertaken with American university students and therefore offers no cross-cultural aspect, we can understand that approaches to shock advertising can draw out potential benefits as well as having differing impacts on differing cultures.

Two studies investigated shock advertising and cross-cultural reactions. Huhmann and Mott-Stenerson (2008) compared two cultures (Hispanic and non-Hispanic white) and also looked at the issue of gender. They found that neither gender nor ethnic identity affected the processing of shock advertising. This study was not limited to exploring the effects of shock advertising and different cultures but also related to the processing and comprehension ability of different genders/ethnic origin regarding controversial (i.e. shock) and non-controversial advertisements. The study used undergraduate and graduate university students, as in the current research. Building on this, Krstic (2007) compared Serbian and Western European students in a small scale qualitative study in terms of their reaction to shock advertising. However, the main objective of this study was to compare reactions towards public health shock advertising and the research only looked at cultural differences in terms of Serbia being defined as a more conservative country. She concluded that Serbian participants showed stronger reaction to shock advertising than their western-European counterparts. Indeed, these studies highlight how varied and complex reactions to shock advertising can be.

\section{Ethno-Cultural Diversity within National Societies}

As stated earlier, nations such as the UK are becoming less and less homogenous. Within domiciles in individual countries, the audience base is becoming more complex and varied, and this potentially impacts on intended messages delivered to customers through advertising. The cultural and ethnic roots of the British population are increasingly diverse. De Mooij (2010a, p.64) casts doubt on whether advertisers could ever create just one message to be used globally "because there is not one global culture comprised of people with identical values". Not only is the notion of global culture very doubtful, even the idea of national culture must be called into question. As Appiah (2016) tells in his Reith lecture series, nations are not only invented but continuously reinvented. "Once, to be English, you had to imagine your ancestors were recorded a millennium ago in the Doomsday Book. Now a Rohit or a Pavel or a Muhammad or a Kwame can be English". Antonisich and Mavroudi (2015) 
also make reference to the new international mobility and increased ethno-cultural pluralism of populations.

Marketers are starting to recognise the importance of taking a more multicultural approach in media conversations with consumers within the same country. Examples of this were mentioned by Wentz (2015) regarding the US consumer market. Even a country with a long history of a diverse ethnic consumer base, such as the USA, is still struggling to find the right approach to talk to multicultural consumers and practitioners are questioning whether they need in-house multicultural marketing departments (Wentz 2015).

\section{Ethnicity and Shock Advertising}

The correlation between the ethnicity of actors in adverts and those viewing the advert has been the subject of a number of studies. Sierra et al. (2009) used subjects from Hispanic as well as black and white American backgrounds and came to the conclusion that the shared ethnicity of the actors in the advert and of those viewing the advert can have a positive impact for the advert and the brand. Ueltschy (2011) came to a similar conclusion regarding the use of Hispanic actors. However, in this study, the ethnicity factor only became significant for what was termed as strong Hispanics, i.e. Hispanics who felt more Hispanic than American. Research by Elias and Appiah (2010) into the different reactions of black and white American subjects again found a stronger impact for a particular group. Whilst white subjects were indifferent to the ethnicity in the adverts, black subjects from a majority white environment reacted more favourably to adverts with a black spokesperson than black subjects from a majority black environment.

Some studies have also looked at ethnicity involving Asian subjects. Martin, Lee and Young (2004) found that Asian consumers relate more to an advert if they see an Asian model. In this research the Asians once again lived in an Asian minority environment in New Zealand. However, Cui and Yang (2009) looked at Chinese consumers within the Chinese market and found that the same was true in a Chinese majority environment. They went on to caution advertisers' use of Caucasian models when targeting Chinese consumers with sex appeal adverts. Two studies by Zebrowitz et al. (2007, p.306) examined Korean and white Americans, as well as black and white Americans, and concluded that "people tend to respond to unfamiliar faces of strangers with general negativity". Carrabis and Peverill-Cotti (2011) state that culture tends to define beauty; thus, certain traits and physiognomies are valued differently depending on the culture.

In an earlier study, Engelbart and Jackson (2011) found that the ethnicity of the actors and the background environment in an advert had a greater impact on the reaction to the shock element of the advert than the degree of shock itself. The study had included subjects from European and Asian countries. The current larger sample study is again using European and Asian students living in the UK as international students, therefore in a minority environment. However, as Brie (2010) points out, Europeans feel part of a common cultural area whilst the Asian students are clearly a minority group. Thus, we expect to find that: 


\section{Hypothesis 1 (H1): Asian and European participants will display differing levels of shock when presented with adverts from differing cultural contexts.}

\section{Hypothesis 2 (H2): Asian participants will be more shocked by adverts} where the actors are of South-Asian origin.

\section{Gender Related Research}

Several studies conclude that there is a difference between genders in relation to emotional appeals and their reaction to offensive advertising. Chu et al. (2006) discuss within country differences by gender and ethnic background (white, African American, Asian American and Hispanic) that across cultures women are more likely to have sympathy for victims. Wang (2008) uses Hong Kong adverts and students to conclude that females respond better to emotional appeals in public service advertising whilst males do not show a clear difference in their response whether the advert is rational or emotional. Earlier research by Waller (1999) suggested that females were significantly more offended than males by offensive advertising and that it was the execution of the advertising which offended them the most.

However, other research suggests that gender related differences are not the same across all societies and cultures. Nelson et al. (2006) carried out their research in both feminine and masculine cultures and concluded that women in masculine societies are other-focused and men are self-focused, but in a feminine society like Denmark the opposite was found to be the case.

Differences were also recorded in research undertaken using Asian countries. Peak et al. (2011) conducted a study across 6 countries (Brazil, Canada, China, Germany, South-Korea, Thailand and the United States) analysing gender role portrayal in television advertising. They came to the conclusion that there was an interesting difference in the portrayal of gender specific roles between women in adverts in South-Korea and China. In China, women were less frequently portrayed as homemakers. They explained this by the Communist led government in China having made an effort to see women as a workforce rather than homemakers. They concluded that this made China different from other Asian countries.

Waller et al. (2013) examined the reactions of 930 university students from six countries to violent images in advertising. They found that Turkish and Kazak participants reacted much more strongly against offensive advertising than Indians, South-Koreans, Australians and Canadians. In terms of gender, women from all cultures were offended more than men by violent images and the intensity of religious beliefs led to a significantly more negative reaction from participants across the cultures. They also find that there is still a paucity of studies pertaining to crosscultural research into the area of violent images in advertising. Thus, we expect to find that:

\section{Hypothesis 3 (H3): Female participants (whether Asian or European) will react more strongly to shocking adverts than males.}




\section{Methodology}

The current study was carried out in the UK using 115 national and international undergraduate university students from 6 countries (China, France, Germany, Japan, Spain and the UK - see Table 1). Waller et al. (2013) stress the importance of sample equivalence in large cross-cultural studies and see the use of student samples as a viable method to do this. In an earlier study, it was argued that using students in crosscultural comparisons of attitudes has other benefits such as establishing equivalence so that any cultural differences are highlighted (Dant and Barnes 1988, cited by Fam and Waller 2003).

Table 1: Frequency of Nationalities and Gender

\begin{tabular}{|c|c|c|c|}
\hline & & Frequency & Percentage \\
\hline \multirow{5}{*}{ European } & German & 27 & 23.5 \\
\hline & British & 12 & 10.4 \\
\hline & French & 11 & 9.6 \\
\hline & Spanish & 9 & 7.8 \\
\hline & Total & 59 & 51.3 \\
\hline \multirow[t]{3}{*}{ Asian } & Chinese & 53 & 46.1 \\
\hline & Japanese & 3 & 2.6 \\
\hline & Total & 56 & 48.7 \\
\hline \multirow[t]{3}{*}{ Gender } & Male & 43 & 37.4 \\
\hline & Female & 72 & 62.6 \\
\hline & Total & 115 & 100 \\
\hline
\end{tabular}

From the sample of students used, the frequency of nationalities reflects the proportions of nationalities within the programmes targeted. Indeed, these programmes were targeted because of their rich diversity of international student population. The relatively equal split between European and Asian nationalities has allowed for particular analyses within this regard. Furthermore, more females were involved in general within this study and this also effectively reflects the study sample used.

The students were exposed to seven television adverts on safe driving from 4 countries. Only one of the shock adverts was from an Asian country and one advert was used as a control (also Asian), i.e. it did not include 'shock' content. These adverts are considered a form of social education (Waller et al. 2014). Table 2 provides a general breakdown of the adverts used and further details, including a description and web link, can be found in Appendix 1.

The aim of the study was to see if the participants would react differently to the degree of shock, as well as the culture depicted in the advert (H1). A further aim was to see if there were gender related differences in the reactions of participants (H2). The shock levels of the adverts ranged from very shocking and graphic imagery (advert 7) to mildly shocking imagery (advert 4) (see Appendix 1). The students were given a questionnaire to complete whilst watching all 7 adverts in one sitting. The questionnaire asked students to rate each advert using a traditional 1-5 Likert scale. A similar approach to Fam et al. (2009), who applied a Likert scale 1-5 (ranging from 1, not at all offensive, to 5 extremely offensive) in their research into controversial advertising, was adopted. Our participants were asked to indicate their degree of shock ranging from 1 , not shocked at all, to 5, so shocked that this would stay with 
them for some time. It was decided that, for the purposes of this study, levels 1 and 2 were weighted as non-shocking (I feel perfectly comfortable watching this and probably won't think about it again (level 1), I feel slightly uncomfortable (level 2)), whilst levels 3 to 5 were considered to be understood as shocking to varying degrees (I feel uncomfortable (level 3), I feel very uncomfortable (level 4), I feel disturbed by this ad and may think about it afterwards (level 5)). Furthermore, we gathered qualitative data at the end of the adverts to gain further insight into the effects of shock on the participants.

Table 2: Breakdown of Adverts Used

\begin{tabular}{|l|l|l|l|l|}
\hline Advert & $\begin{array}{l}\text { Country } \\
\text { of origin }\end{array}$ & Theme & Gender shock focus & Year made \\
\hline 1 & UK & Drink-driving & $\begin{array}{l}\text { Males depicted as guilty, } \\
\text { female as victim }\end{array}$ & $\begin{array}{l}\text { 2004: Think } \\
\text { Campaign }\end{array}$ \\
\hline 2 & France & Drink-driving & $\begin{array}{l}\text { Male as guilty and as } \\
\text { victim }\end{array}$ & $\begin{array}{l}\text { 2010: Sécurité } \\
\text { routière : Le rescapé }\end{array}$ \\
\hline 3 & Germany & $\begin{array}{l}\text { Importance of } \\
\text { safety belt }\end{array}$ & $\begin{array}{l}\text { Child victim, } \\
\text { Parents guilty }\end{array}$ & $\begin{array}{l}\text { 2009: Gurte retten } \\
\text { Leben }\end{array}$ \\
\hline 4 & Thailand & Dangerous driving & $\begin{array}{l}\text { Young couple victims } \\
\text { and male driver of couple } \\
\text { guilty }\end{array}$ & $\begin{array}{l}\text { 2006: Don't speed, } \\
\text { road safety } \\
\text { campaign }\end{array}$ \\
\hline 5 & Thailand & $\begin{array}{l}\text { Humorous anti } \\
\text { drink-driving }\end{array}$ & $\begin{array}{l}\text { No victims or guilty } \\
\text { parties (control group) }\end{array}$ & $\begin{array}{l}\text { 2005: Thai whisky } \\
\text { advert }\end{array}$ \\
\hline 6 & USA & Drink-driving & $\begin{array}{l}\text { Female victim, male } \\
\text { guilty }\end{array}$ & $\begin{array}{l}\text { 2002: Save a life } \\
\text { campaign }\end{array}$ \\
\hline 7 & $\begin{array}{l}\text { Northern } \\
\text { Ireland }\end{array}$ & Dangerous driving & $\begin{array}{l}\text { Male and female victim, } \\
\text { effects on their families, } \\
\text { male guilty }\end{array}$ & $\begin{array}{l}\text { 2007: DOE } \\
\text { Mess campaign }\end{array}$ \\
\hline
\end{tabular}

We inputted all data into SPSS to conduct an analysis. Means and standard deviations were calculated to highlight two levels of significance, at 0.05 and 0.005 . The former is further highlighted in the results by * to signal an area of significance and the latter is highlighted with $* *$ to signal an area of high significance. Post hoc techniques were applied, where needed and relevant, to build rigour into the findings, including one ANOVA, one one-way ANOVA with Tukey's adjustment, two-way unrelated ANOVAs, one unrelated t-test, independent samples t-tests and Bonferroni adjustments.

\section{Results}

Table 3 represents means and standard deviation data from all adverts used within the study. Crucially, the subsequent examination of results will concentrate on the three adverts where significance has been highlighted, i.e. advert 3, 4 and 7 .

Table 3: Means and Standard Deviations for All Adverts by Gender, Region and Nationality

\begin{tabular}{|l|l|l|l|l|l|l|l|l|l|}
\hline Gender & Region & Nationality & Ad1 & Ad2 & Ad3 & Ad4 & Ad5 & Ad6 & Ad7 \\
\hline Male & Europe & British & 1.86 & 2.86 & 2.29 & 1.29 & 1.14 & 3.29 & 3.57 \\
& & & $(0.69)$ & $(1.22)$ & $(1.60)$ & $(0.49)$ & $(0.38)$ & $(1.11)$ & $(1.62)$ \\
\cline { 3 - 9 } & & German & 2.17 & 3.00 & 3.00 & 1.33 & 1.00 & 4.00 & 3.67 \\
& & & $(0.75)$ & $(0.89)$ & $(0.89)$ & $(0.52)$ & $(0.00)$ & $(0.89)$ & $(0.82)$ \\
\hline
\end{tabular}




\begin{tabular}{|c|c|c|c|c|c|c|c|c|c|}
\hline & & Spanish & $\begin{array}{l}2.25 \\
(0.96)\end{array}$ & $\begin{array}{l}2.75 \\
(1.26)\end{array}$ & $\begin{array}{l}2.50 \\
(1.00)\end{array}$ & $\begin{array}{l}2.00 \\
(0.82)\end{array}$ & $\begin{array}{l}1.50 \\
(1.00)\end{array}$ & $\begin{array}{l}3.75 \\
(1.89)\end{array}$ & $\begin{array}{l}3.00 \\
(1.41)\end{array}$ \\
\hline & & French & $\begin{array}{l}2.00 \\
(1.41)\end{array}$ & $\begin{array}{l}3.14 \\
(1.57)\end{array}$ & $\begin{array}{l}1.57 \\
(0.89)\end{array}$ & $\begin{array}{l}1.00 \\
(0.00)\end{array}$ & $\begin{array}{l}1.00 \\
(0.00)\end{array}$ & $\begin{array}{l}2.17 \\
(0.95)\end{array}$ & $\begin{array}{l}2.79 \\
(1.11)\end{array}$ \\
\hline & & Total & $\begin{array}{l}2.04 \\
(0.96)\end{array}$ & $\begin{array}{l}2.96 \\
(1.20)\end{array}$ & $\begin{array}{l}2.29 \\
(1.20)\end{array}$ & $\begin{array}{l}1.33 \\
(0.57)\end{array}$ & $\begin{array}{l}1.13 \\
(0.45)\end{array}$ & $\begin{array}{l}3.38 \\
(1.21)\end{array}$ & $\begin{array}{l}3.54 \\
(1.22)\end{array}$ \\
\hline & \multirow[t]{3}{*}{ Asia } & Chinese & $\begin{array}{l}2.47 \\
(0.96)\end{array}$ & $\begin{array}{l}2.89 \\
(1.10)\end{array}$ & $\begin{array}{l}2.47 \\
(1.26)\end{array}$ & $\begin{array}{l}1.68 \\
(0.82)\end{array}$ & $\begin{array}{l}1.63 \\
(1.34)\end{array}$ & $\begin{array}{l}3.63 \\
(0.96)\end{array}$ & $\begin{array}{l}3.71 \\
(1.44)\end{array}$ \\
\hline & & Japanese & - & - & - & - & - & - & - \\
\hline & & Total & $\begin{array}{l}2.47 \\
(0.96)\end{array}$ & $\begin{array}{l}2.89 \\
(1.10)\end{array}$ & $\begin{array}{l}2.47 \\
(1.26)\end{array}$ & $\begin{array}{l}1.68 \\
(0.82)\end{array}$ & $\begin{array}{l}1.63 \\
(1.34)\end{array}$ & $\begin{array}{l}3.63 \\
(0.96)\end{array}$ & $\begin{array}{l}2.79 \\
(1.44)\end{array}$ \\
\hline & Both & Total & $\begin{array}{l}2.23 \\
(0.97)\end{array}$ & $\begin{array}{l}2.93 \\
(1.14)\end{array}$ & $\begin{array}{l}.37 \\
(1.22) * *\end{array}$ & $\begin{array}{l}1.49 \\
(0.70) * *\end{array}$ & $\begin{array}{l}1.35 \\
(0.97)\end{array}$ & $\begin{array}{l}3.49 \\
(1.10)\end{array}$ & $\begin{array}{l}3.21 \\
(1.36) * *\end{array}$ \\
\hline \multirow[t]{9}{*}{ Female } & \multirow[t]{5}{*}{ Europe } & British & $\begin{array}{l}2.40 \\
(1.14)\end{array}$ & $\begin{array}{l}3.20 \\
(1.30)\end{array}$ & $\begin{array}{l}3.40 \\
(1.52)\end{array}$ & $\begin{array}{l}1.80 \\
(1.30)\end{array}$ & $\begin{array}{l}1.00 \\
(0.00)\end{array}$ & $\begin{array}{l}4.40 \\
(0.58)\end{array}$ & $\begin{array}{l}4.60 \\
(0.55)\end{array}$ \\
\hline & & French & $\begin{array}{l}2.25 \\
(1.23)\end{array}$ & $\begin{array}{l}3.00 \\
(0.82)\end{array}$ & $\begin{array}{l}2.25 \\
(1.26)\end{array}$ & $\begin{array}{l}1.25 \\
(0.50)\end{array}$ & $\begin{array}{l}1.00 \\
(0.00)\end{array}$ & $\begin{array}{l}3.75 \\
(1.26)\end{array}$ & $\begin{array}{l}4.57 \\
(0.60)\end{array}$ \\
\hline & & German & $\begin{array}{l}2.90 \\
(1.00)\end{array}$ & $\begin{array}{l}3.71 \\
(1.34)\end{array}$ & $\begin{array}{l}3.52 \\
(0.98)\end{array}$ & $\begin{array}{l}1.90 \\
(0.54)\end{array}$ & $\begin{array}{l}1.00 \\
(0.00)\end{array}$ & $\begin{array}{l}4.38 \\
(0.59)\end{array}$ & $\begin{array}{l}4.20 \\
(0.84)\end{array}$ \\
\hline & & Spanish & $\begin{array}{l}3.80 \\
(1.64)\end{array}$ & $\begin{array}{l}3.40 \\
(1.34)\end{array}$ & $\begin{array}{l}3.40 \\
(1.82)\end{array}$ & $\begin{array}{l}2.40 \\
(1.14)\end{array}$ & $\begin{array}{l}1.20 \\
(0.45) \\
\end{array}$ & $\begin{array}{l}3.40 \\
(1.82)\end{array}$ & $\begin{array}{l}4.67 \\
(0.96) \\
\end{array}$ \\
\hline & & Total & $\begin{array}{l}2.89 \\
(1.18)\end{array}$ & $\begin{array}{l}3.51 \\
(1.01)\end{array}$ & $\begin{array}{l}3.34 \\
(1.24)\end{array}$ & $\begin{array}{l}1.89 \\
(0.80)\end{array}$ & $\begin{array}{l}1.03 \\
(1.17)\end{array}$ & $\begin{array}{l}4.17 \\
(0.95)\end{array}$ & $\begin{array}{l}4.49 \\
(0.66)\end{array}$ \\
\hline & \multirow[t]{3}{*}{ Asia } & Chinese & $\begin{array}{l}2.47 \\
(0.99)\end{array}$ & $\begin{array}{l}3.21 \\
(0.98)\end{array}$ & $\begin{array}{l}3.26 \\
(1.24)\end{array}$ & $\begin{array}{l}2.50 \\
(1.16)\end{array}$ & $\begin{array}{l}1.38 \\
(1.16)\end{array}$ & $\begin{array}{l}3.71 \\
(1.09)\end{array}$ & $\begin{array}{l}2.97 \\
(1.14)\end{array}$ \\
\hline & & Japanese & $\begin{array}{l}3.67 \\
(1.53)\end{array}$ & $\begin{array}{l}4.00 \\
(0.00)\end{array}$ & $\begin{array}{l}4.00 \\
(1.00)\end{array}$ & $\begin{array}{l}3.00 \\
(1.00)\end{array}$ & $\begin{array}{l}1.33 \\
(0.58)\end{array}$ & $\begin{array}{l}4.33 \\
(1.16)\end{array}$ & $\begin{array}{l}4.25 \\
(0.58)\end{array}$ \\
\hline & & Total & $\begin{array}{l}2.57 \\
(1.09)\end{array}$ & $\begin{array}{l}3.27 \\
(0.96)\end{array}$ & $\begin{array}{l}3.32 \\
(1.23)\end{array}$ & $\begin{array}{l}2.54 \\
(1.15)\end{array}$ & $\begin{array}{l}1.38 \\
(1.11)\end{array}$ & $\begin{array}{l}3.76 \\
(1.09)\end{array}$ & $\begin{array}{l}3.11 \\
(1.20)\end{array}$ \\
\hline & Both & Total & $\begin{array}{l}2.72 \\
(1.13)\end{array}$ & $\begin{array}{l}3.39 \\
(0.99)\end{array}$ & $\begin{array}{l}3.33 \\
(1.22) * *\end{array}$ & $\begin{array}{l}2.22 \\
(1.04)^{* * *}\end{array}$ & $\begin{array}{l}1.21 \\
(0.82)\end{array}$ & $\begin{array}{l}3.96 \\
(1.04)\end{array}$ & $\begin{array}{l}3.78 \\
(1.19)^{* *}\end{array}$ \\
\hline \multirow[t]{9}{*}{ Total } & \multirow[t]{5}{*}{ Europe } & British & $\begin{array}{l}2.08 \\
(0.90)\end{array}$ & $\begin{array}{l}3.00 \\
(1.21)\end{array}$ & $\begin{array}{l}2.75 \\
(1.60)\end{array}$ & $\begin{array}{l}1.50 \\
(0.91)\end{array}$ & $\begin{array}{l}1.08 \\
(0.29)\end{array}$ & $\begin{array}{l}3.75 \\
(1.06)\end{array}$ & $\begin{array}{l}4.00 \\
(1.35)\end{array}$ \\
\hline & & German & $\begin{array}{l}2.74 \\
(0.98)\end{array}$ & $\begin{array}{l}3.56 \\
(0.93)\end{array}$ & $\begin{array}{l}3.41 \\
(0.97)\end{array}$ & $\begin{array}{l}1.78 \\
(0.58)\end{array}$ & $\begin{array}{l}1.00 \\
(0.00)\end{array}$ & $\begin{array}{l}4.30 \\
(0.67)\end{array}$ & $\begin{array}{l}4.37 \\
(0.74)\end{array}$ \\
\hline & & Spanish & $\begin{array}{l}3.11 \\
(1.54)\end{array}$ & $\begin{array}{l}3.11 \\
(1.27)\end{array}$ & $\begin{array}{l}3.00 \\
(1.50)\end{array}$ & $\begin{array}{l}2.22 \\
(0.97)\end{array}$ & $\begin{array}{l}1.33 \\
(0.70)\end{array}$ & $\begin{array}{l}3.56 \\
(1.74)\end{array}$ & $\begin{array}{l}3.67 \\
(1.23)\end{array}$ \\
\hline & & French & $\begin{array}{l}2.09 \\
(1.30)\end{array}$ & $\begin{array}{l}3.09 \\
(1.30)\end{array}$ & $\begin{array}{l}1.82 \\
(0.98)\end{array}$ & $\begin{array}{l}1.09 \\
(0.30)\end{array}$ & $\begin{array}{l}1.00 \\
(0.00)\end{array}$ & $\begin{array}{l}3.09 \\
(1.14)\end{array}$ & $\begin{array}{l}3.91 \\
(1.04)\end{array}$ \\
\hline & & Total & $\begin{array}{l}2.54 \\
(1.16)\end{array}$ & $\begin{array}{l}3.29 \\
(1.12)\end{array}$ & $\begin{array}{l}2.92 \\
(1.32)\end{array}$ & $\begin{array}{l}1.66 \\
(0.76)^{* *}\end{array}$ & $\begin{array}{l}1.07 \\
(0.31)\end{array}$ & $\begin{array}{l}3.85 \\
(1.13)\end{array}$ & $\begin{array}{l}4.10 \\
(1.03) * *\end{array}$ \\
\hline & \multirow[t]{3}{*}{ Asia } & Chinese & $\begin{array}{l}2.47 \\
(0.97)\end{array}$ & $\begin{array}{l}3.09 \\
(1.02)\end{array}$ & $\begin{array}{l}2.98 \\
(1.29)\end{array}$ & $\begin{array}{l}2.21 \\
(1.12)\end{array}$ & $\begin{array}{l}1.47 \\
(1.22)\end{array}$ & $\begin{array}{l}3.68 \\
(1.03)\end{array}$ & $\begin{array}{l}2.91 \\
(1.24)\end{array}$ \\
\hline & & Japanese & $\begin{array}{l}3.67 \\
(1.53)\end{array}$ & $\begin{array}{l}4.00 \\
(0.00)\end{array}$ & $\begin{array}{l}4.00 \\
(1.00)\end{array}$ & $\begin{array}{l}3.00 \\
(1.00)\end{array}$ & $\begin{array}{l}1.33 \\
(0.58)\end{array}$ & $\begin{array}{l}4.33 \\
(1.16)\end{array}$ & $\begin{array}{l}4.67 \\
(0.58)\end{array}$ \\
\hline & & Total & $\begin{array}{l}2.54 \\
(1.03)\end{array}$ & $\begin{array}{l}3.14 \\
(1.02)\end{array}$ & $\begin{array}{l}3.04 \\
(1.29)\end{array}$ & $\begin{array}{l}2.25 \\
(1.12) * *\end{array}$ & $\begin{array}{l}1.46 \\
(1.19)\end{array}$ & $\begin{array}{l}3.71 \\
(1.04)\end{array}$ & $\begin{array}{l}3.00 \\
(1.28)^{* *}\end{array}$ \\
\hline & Both & Total & $\begin{array}{l}2.54 \\
(1.10)\end{array}$ & $\begin{array}{l}3.22 \\
(1.07)\end{array}$ & $\begin{array}{l}2.97 \\
(1.30)\end{array}$ & $\begin{array}{l}1.95 \\
(0.99)\end{array}$ & $\begin{array}{l}1.26 \\
(0.88)\end{array}$ & $\begin{array}{l}3.78 \\
(1.08)\end{array}$ & $\begin{array}{l}3.57 \\
(1.28)\end{array}$ \\
\hline
\end{tabular}




\section{Advert 3 - European Advert: Gender Differences}

Table 4 provides the collective descriptive statistics that were calculated for advert 3. Although the table shows that there are negligible differences between the Europeans and the Asians, there is a significant difference between the males and females. A two-way unrelated ANOVA for advertisement 3 found a significant main effect for gender only $\left(\mathrm{F}(1,111)=15.972, \mathrm{p}=0.000\right.$, partial eta $\left.{ }^{2}=0.126\right)$. Therefore, a posthoc independent samples t-test was run to assess this, which also proved significant even with a Bonferroni adjustment $(\mathrm{t}(113)=-4.090, \mathrm{p}=0.000)$.

Table 4: Means and Standard Deviations by Gender and Nationality for Advertisement 3

\begin{tabular}{|l|l|l|l|}
\hline & Male & Female & Total \\
\hline European & $2.29(1.20)$ & $3.34(1.24)$ & $2.92(1.14)$ \\
\hline Asian & $2.47(1.26)$ & $3.32(1.23)$ & $3.04(1.29)$ \\
\hline Total & $2.37(1.22)$ & $3.33(1.22)$ & $3.97(1.30)$ \\
\hline
\end{tabular}

The qualitative data collected also highlights a strong gender difference. When asked about how successful the advert was, the following provides key examples of the gender split:
"It was not very effective" (German male respondent);
"Not really, because we notice that the girl at the end is a fake girl" (French male respondent);
"Yes, the child flying through the front window is a realistic consequence"
(German female respondent);
"No it's just too sad. I don't like it" (Chinese female respondent).

\section{Advert 4 - Asian Advert: Cultural and Gender Differences}

The descriptive statistics within Table 5 show that there are some differences between Europeans and Asians, as well as males and females.

Table 5: Means and Standard Deviations by Gender and Nationality for Advertisement 4

\begin{tabular}{|l|l|l|l|}
\hline & Male & Female & Total \\
\hline European & $1.33(0.57)$ & $1.89(0.80)$ & $1.66(0.76)$ \\
\hline Asian & $1.68(0.82)$ & $2.54(1.15)$ & $2.25(1.12)$ \\
\hline Total & $1.49(0.70)$ & $2.22(1.04)$ & $1.95(0.99)$ \\
\hline
\end{tabular}

Thus, not only does there appear to be a clear difference between the nationalities, in that the Asians scored higher than the Europeans, but there also appears to be a difference between the genders, in that females score higher than males, more so among the Asians. This is supported by a two-way unrelated ANOVA for advertisement 4 which found a significant main effect for gender $(F(1,111)=16.667$, $\mathrm{p}=0.000$, partial eta $\left.{ }^{2}=0.131\right)$, and nationality only $(\mathrm{F}(1,111)=8.495, \mathrm{p}=0.004$, partial eta $\left.^{2}=0.071\right)$. Both factors were further tested using post-hoc independent samples t-tests, which found significant differences $(\mathrm{t}(113)=-4.106, \mathrm{p}=0.000)$ between the genders and significant differences $(\mathrm{t}(113)=-3.327, \mathrm{p}=0.001)$ between Europeans and Asians, even with Bonferroni adjustments. The qualitative data collected adds depth to understanding the differences between Asian and European cultures: 
"It's rather funny than shocking" (German male respondent);

"It is not successful. It is not shocking enough to make one think about it"

(British female respondent);

"The ending is too scary" (Chinese female respondent).

\section{Advert 7 - European Advert: Cultural and Gender Differences}

The descriptive statistics within Table 6 show that there are slight differences between the Europeans and the Asians, as well as the males and females.

Table 6: Means and Standard Deviations by Gender and Nationality for Advertisement 7

\begin{tabular}{|l|l|l|l|}
\hline & Male & Female & Total \\
\hline European & $3.54(1.22)$ & $4.49(0.66)$ & $4.10(1.03)$ \\
\hline Asian & $2.79(1.44)$ & $3.11(1.20)$ & $3.00(1.28)$ \\
\hline Total & $3.21(1.36)$ & $3.78(1.12)$ & $3.57(1.28)$ \\
\hline
\end{tabular}

While Europeans seem to have scored higher than the Asians in terms of their shock level, little differences are apparent among the Asian males and females. It is among the Europeans that the greater gender difference exists. A two-way unrelated ANOVA for advertisement 7 found significant main effects for gender $(\mathrm{F}(1,111)=8.591, \mathrm{p}=$ 0.004 , partial eta $\left.{ }^{2}=0.072\right)$, and nationality only $(\mathrm{F}(1,111)=24.442, \mathrm{p}=0.000$, partial eta $\left.{ }^{2}=0.180\right)$. Both were therefore further tested using post-hoc independent samples t-tests, which found significant differences $(\mathrm{t}(113)=5.102, \mathrm{p}=0.000)$ between Europeans and Asians, but not between the genders $(\mathrm{t}(113)=-2.353, \mathrm{p}=$ 0.020), even with Bonferroni adjustments, suggesting that while culture impacts greatly on shock reactions, the genders do not noticeably differ.

A separate ANOVA was done for gender and nationality as broken down into nationalities and not simply Asian and European categories. A two-way unrelated ANOVA found significant main effects for gender $(F(4,104)=8.180, p=0.005$, partial eta $\left.{ }^{2}=0.073\right)$ and nationality only $\left(\mathrm{F}(4,104)=5.561, \mathrm{p}=0.000\right.$, partial eta ${ }^{2}=$ 0.211). A post hoc one-way ANOVA with Tukey's adjustment for nationality showed only two significant results: between the German and the Chinese $(0.000)$ and the British and the Chinese (0.034). A post-hoc unrelated t-test showed a significant difference between the genders $(\mathrm{t}(113)=-2.353, \mathrm{p}=0.020)-$ see Figure 1 . 


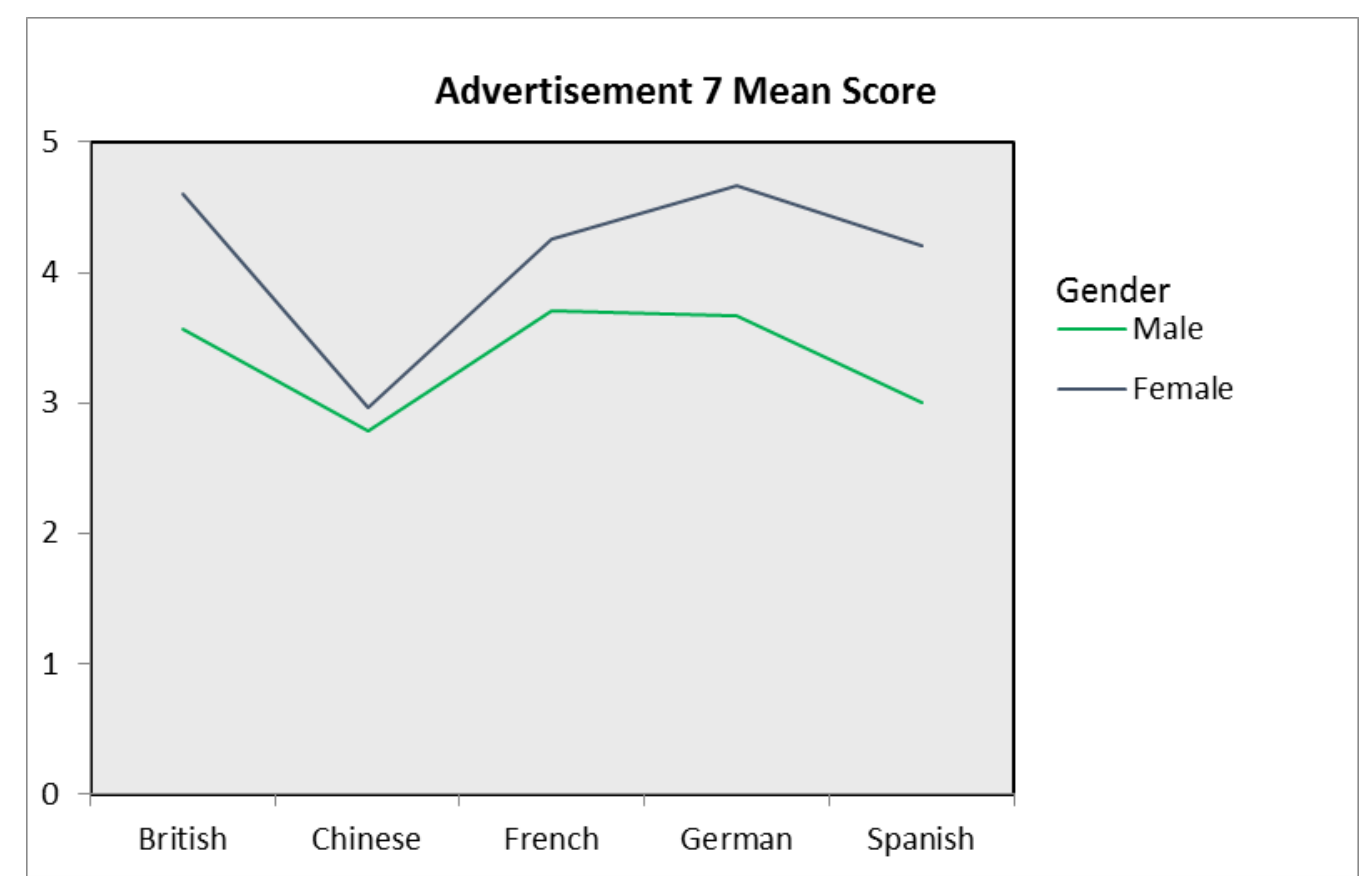

Figure 1: Plotted Mean Score by Individual Nationality and Gender on Advertisement 7

The following qualitative data adds depth to understanding the differences between genders when asked whether the advert shocked them, specifically why Chinese females are perhaps less affected:

"Terrible and cruel" (German female respondent);

"Yes, without a doubt it's an upsetting ad and it does make you think about speeding" (British male respondent);

"Yes. It was traumatic and got across all the right messages" (British female respondent);

"No. It's likely to be a disaster movie, not an ad." (Chinese female respondent).

\section{Discussion}

$\mathrm{H} 1$ and $\mathrm{H} 2$ relate to finding out if Asian participants would differ in shock and be more shocked than their European counterparts if the advert had a differing cultural setting. Advert 4 showed Asian countryside, Asian vehicles and Asian actors. H1 and $\mathrm{H} 2$ can be upheld for advert 4, particularly in so far as Asian females scored significantly higher than all other participants, although Asian males also scored higher than European males. This mirrors the findings of studies by Martin et al. (2004) and Cui and Yang (2009) relating to Chinese consumers. However, these studies were conducted in New Zealand and China respectively and other studies into the importance of ethnicity in advertising were conducted in the USA, but not in Europe. Therefore, this study is significant because it is UK based and includes the European perspective. The differences in the perception of advert 4 between the European and Asian participants is also underpinned by the comments made by the German and British participants who dismiss advert 4 as not being shocking enough or even as funny, whilst the Chinese comment describes the ending as too scary. Results from Advert 7 which features European actors and environment also confirm H1 in that European participants are more shocked than Asian participants. Whilst 
European participants brand this advert as terrible, cruel, upsetting or even traumatic, the Asian reaction questioned the realism depicted in the advert, comparing it to a disaster movie.

According to the Higher Education Statistics Agency (2016), the number of Chinese first year undergraduate students became the largest group of foreign students entering the UK in 2012 and maintained this increase in the following years, overtaking the number of EU students in the UK. According to the Office of National Statistics (2016), in $20114.2 \%$ of the UK population were of Chinese origin and form a not insignificant target market for shock advertising, including dangerous driving or drink driving in the UK.

Furthermore, advert 4 relied heavily on visual impact which is highly suited to indirect communication styles and this may explain the very different reaction from European and Asian participants. This correlates to research by Chan et al. (2007) who highlight a cultural difference between German and Chinese subjects in that they found a significant difference in what Chinese and German students perceive as being informative. Emphasis was on the fact that Germans, from a low-context culture, needed more objective information than Chinese subjects from a high-context culture. The advertisements used relied heavily on images rather than objective information and were less suitable for low context cultures.

$\mathrm{H} 3$ relates to finding out if females react more negatively to shocking ads than males. $\mathrm{H} 3$ can be upheld as seen from the results of advert 3 in particular since all females were significantly more shocked than the males. It was a European advert with European actors and settings. All females were more shocked by advert 4 and 7 . However, as previously stated: Asian females reacted significantly stronger to advert 4; European females slightly more to advert 7; and all females significantly more to advert 3. The affectionate mother-daughter relationship depicted in advert 3 followed by the death of the little girl may have triggered more empathy from female participants than males. This correlates to research carried out by Chu et al. (2006) which found that across cultures, women are more likely to have sympathy for victims. Waller et al. (2013) also found that in terms of gender, women from all cultures were offended more than men by violent images.

The outcome regarding advert 7 surprised us to some degree. We saw this as the most shocking advert on various levels and believed that the story involving not just the immediately affected victims but also their families and the driver would trigger strong reactions from all nationalities. However, only the European females showed such a strong reaction. All European participants, including the males, showed a stronger reaction to advert 7 than the Chinese participants. As the actors in the advert were all Caucasians, this further contributes to the confirmation of $\mathrm{H} 1$ and $\mathrm{H} 2$.

\section{Conclusion}

This study examines the reactions of participants from Europe and Asia to shock TV advertising in the NFP sector using 7 adverts from different countries around the world. The main purpose was to identify if the gender and ethnicity of the participants affected their degree of shock. From the results, it has become clear that there is a significant difference in the reaction of participants if their own ethnicity is portrayed 
in the advert. This was true for Asian participants regarding an advert showing Asian actors (advert 4) and also for European participants regarding an advert showing European actors (advert 7). Furthermore, the results also showed significant difference in the reactions of male and female participants regarding the degree of shock displayed in all adverts, whereby the female reaction was always stronger than the reaction of the male participants.

For advertisers and marketers within the NFP sector whose aim is to increase awareness of dangerous behaviour in particular and for international marketers, we suggest it is important to include actors from different ethnic backgrounds (or other cross-cultural strategies) in order to reach an increasingly diverse population. Poggi (2015) highlights the fact that US TV channels are only just starting to adopt a multicultural dimension in their programming along the lines of what US marketers have adopted in recent years; in particular, a raised awareness that ads should be created in such a way that the actors in them reflect what the consumers actually look like.

Taking the drinks industry as an example, Moore (2016) states that multicultural consumers are transforming the US market and gives examples of different approaches by the drinks industry to address the local versus global problems arising from multicultural consumer bases. The article highlights a Chivas Regal global campaign which was successful because it was vetted by multicultural teams in the regional offices in 80 countries. In contrast, the British drinks company Innocent has taken the opposite approach (Moore 2016) and has localisation very much at the heart of their global marketing campaigns. Both Chivas and Innocent therefore show great awareness of how cultural differences can affect how consumers respond to advertisements.

In addition, the UK has seen an increased influx of immigrants. This has been particularly significant in the last 25 years and whilst it is not comparable with the US in terms of diversity of consumers, there is, as previously noted, a steady increase of Chinese consumers living in the UK. Therefore, practitioners must be increasingly aware of the diversity of consumers and shy away from the notion of homogenous national consumer behaviour.

As stated early within this paper, this study was carried out to inspire research with a greater body of participants from various backgrounds. Further research using a larger and more balanced sample (equal in terms of gender and ethnicity) is recommended to address sample limitations within our own study. We believe there is a lot of value in further understanding differences between Asian and European cultures, especially in terms of cultures emigrating and engaging with one another. This can lead to a greater understanding of how to target and address diverse audiences and this is particularly relevant to such emotive forms of advertising, whether linked to shock or sex appeal. In addition, where this study primarily focused on a quantitative approach, extensive qualitative data could also be collected to fully understand the complexities of emotional reactions occurring. 


\section{Implications for Business Marketing Practice}

Practitioners should note that, as countries such as the UK become less and less homogenous, the way that they communicate must also take into account the diversity of the consumers. Particularly, where taboo topics, such as shock or indeed sex, are used to grab consumers' attention, reactions from consumers may vary enormously, even within a nation. Whilst the difference in reactions in the current research was much more pronounced between Asian and European subjects, clear differences were also ascertained between different European nationals as could be seen in the different attitudes from German and British participants regarding very shocking ad content. Practitioners should therefore consider the impact which taboo topics in advertisements have on more and more culturally diverse societies, brought about by an era of accelerated international mobility. Furthermore, practitioners should feature in their adverts, actors and cultural triggers reflecting the multicultural aspects of diverse populations.

The message marketers are trying to convey should also take into account the gender of participants since there is a clear indication of the much higher effect of shocking images on females across nations.

\section{References}

Antonsich, M. and Mavroudi, E., (2015), "Ethno-cultural diversity and contemporary national societies", Fennia, vol. 193, no. 2, pp. 160-164.

Appiah, K. A., (2016), "Mistaken Identities: Country", BBC Reith lecture 2016, accessed 11 November 2017, http://www.bbc.co.uk/programmes/b00729d9/episodes/player.

Brie, M., (2010), "European culture between diversity and unity", Annals of University of Oradea - International Relations \& European Studies, vol. 2, pp. 79-92.

Carrabis, C. and Peverill-Cotti, G., (2011), "The selling face: face and body biases in marketing communications", International Journal of Integrated Marketing Communications, vol. 3 , no. 2.

Chan, K., Li, L., Diehl, S. and Terlutter, R., (2007), "Consumers' response to offensive advertising: a cross cultural study", International Marketing Review, vol. 24, no. 5, pp. 606-628.

Chu, T. Q., Seery, M. D., Ence, W. A., Holman, E. A. and Silver, R. C., (2006), "Ethnicity and gender in the face of a terrorist attack: a national longitudinal study of immediate responses and outcomes two years after September 11", Basic and Applied Social Psychology, vol. 28, no. 4, pp. 291-301.

Cui, G. and Yang, X., (2009), "Responses of Chinese consumers to sex appeals in international advertising: a test of congruency theory", Journal of Global Marketing, vol. 22, no. 3, pp. 229-245.

Dahl, D. W., Frankenberg, K. D. and Manchanda, R. V., (2003), "Does it pay to shock? Reactions to shocking and non-shocking advertising content among university participants", Journal of Advertising Research, vol. 43, no. 3, pp. 268-280.

De Mooij, M., (2010a), Global Marketing and Advertising: Understanding Cultural Paradoxes, ( $3^{\text {rd }}$ ed.), London: Sage.

De Mooij, M., (2010b), "Mental Processes across Cultures: Implications for Branding and Communication", Communicative Business, vol. 1, pp. 27-49.

Elias, T. and Appiah, O., (2010), "A Tale of Two Social Contexts", Journal of Advertising Research, vol. 50, no. 3, pp. 250-264.

Engelbart, S.M. and Jackson, D.A., (2011), "Cultural Differences and Shock Advertising in a Global Advertising World", Venice, Italy: ALC Conference. 
Erevelles, S., Morgan, F., Buke, I. and Nguyen, R., (2002), "Advertising Strategy in China: An Analysis of Cultural and Regulatory Factors", Journal of International Consumer Marketing, vol. 15, no. 1, pp. 91-123.

Fam, K. -S. and Waller, D. S. (2003), "Advertising controversial products in the Asia Pacific: what makes them offensive?", Journal of Business Ethics, vol. 48, no. 3, pp. 237-259.

Fam, K. -S., Waller, D. S., Ong F. -S. and Yang, Z. (2008), "Controversial product advertising in China: perceptions of three generational cohorts", Journal of Consumer Behaviour, vol. 7, no. 6, pp. 461-469.

Fam, K. -S., Waller, D. S. and Yang, Z. (2009), "Addressing the advertising of controversial products in China: An empirical approach", Journal of Business Ethics, vol. 88, no. 1, pp. 43-58.

Gao, Z. (2007), "The evolution of Chinese advertising law: A historical review", Advertising Society Review, vol. 8, no. 1.

Hall, E. T. (1976), Beyond Culture, New York: Anchor Books.

Higher Education Statistics Agency, (2016), accessed 28 June 2016 https://www.hesa.ac.uk/stats.

Hofstede, G., (1984), "Cultural Dimensions in Management and Planning", Asia Pacific Journal of Management, vol. 1, no. 2, pp. 81-99.

Huhmann, B. A. and Mott-Stenerson, B. (2008), "Controversial advertisement executions and involvement on elaborative processing and comprehension", Journal of Marketing Communication, vol. 14, no. 4, pp. 293-313.

Javed, M. B. and Zeb, H., (2011), "Good shock or bad shock: what impact shock advertisements are creating on the mind of viewers", In Marketing \& Programme Leader International Business, Annual Conference on Innovations in Business \& Management [London, 2011, January 26-27]. London, University of East London (pp. 1-12).

Krstic, T., (2007), "Attitudes towards Shock Advertising of Western-European and Serbian University Students with Regard to Public Health Context (Anti-Smoking and AntiHIV/AIDS Campaigns)", MA Marketing dissertation, University of Nottingham

Lass, P. and Hart, S., (2004), "National cultures, values and lifestyles influencing consumers' perception towards sexual imagery in alcohol advertising: an exploratory study in the UK, Germany and Italy", Journal of Marketing Management, vol. 20, no. 5/6, pp. 607-623.

Martin, B. A., Lee, C. and Young, F. (2004), "The influence of ad model ethnicity and selfreferencing on attitudes", Journal of Advertising, vol. 33, no. 4, pp. 27-37.

Moore, M. (ed.) (2016), "A glass half full”, The Linguist, vol. 55, no. 5, pp. 22-23.

Nelson, M. R., Brunel, F. F., Supphellen, M. and Manchanda, R., (2006), "Effects of Culture, Gender and Moral Obligations on Responses to Charity Advertising across Masculine and Feminine Cultures", Journal of Consumer Psychology, vol. 16, no. 1, pp. 45-56.

Office of National Statistics (2013), Immigration Patterns of Non-UK Born. Available at: http://webarchive.nationalarchives.gov.uk/20160107164635/http://www.ons.gov.uk/o ns/dcp171776_346219.pdf

Office of National Statistics (2016), 2011 Census analysis: Ethnicity and religion of the nonUK born population in England and Wales. Available at: http://www.ons.gov.uk/peoplepopulationandcommunity/culturalidentity/ethnicity/arti cles/2011 censusanalysisethnicityandreligionofthenonukbornpopulationinenglandand wales/2015-06-18

Paek, H. -J. and Nelson, M. R., (2007), "A Cross-Cultural and Cross-Media Comparison of Female Nudity in Advertising", Journal of Promotion Management, vol. 13, no. 1, pp. 145-167.

Paek, H. -J., Nelson, M. R. and Vilela, A. M. (2011), "Examination of Gender-role Portrayals in Television Advertising across Seven Countries", Sex Roles, vol. 64, no. 3, pp. 192207. 
Parry, S., Jones, R., Stern, P. and Robinson, M., (2013), “'Shockvertising': An exploratory investigation into attitudinal variations and emotional reactions to shock advertising", Journal of Consumer Behaviour, vol. 12, no. 2, pp. 112-121.

Poggi, J., (2015), In Living Color: Diversifying TV Is Good for Advertisers: Media and Marketers Find Adjusting to New Face of America Is Good for the Bottom Line, Advertising Age. Available at: http://adage.com/article/ media/living-colordiversifying-tv-good-advertisers/297903/.

Populations in England and Wales in 2011. Available at: http://www.ons.gov.uk/ ons/rel/census/2011-census-analysis/immigration-patterns-and-characteristics-of-nonuk-born-population-groups-in-england-and-wales/story-on-immigration-patterns-ofnon-uk-born-populations-in-england-and-wales-in-2011.html

Prendergast, G., Cheung, W. -L., and West, D., (2008), "How far is too far? The antecedents of offensive advertising in .modern China", Journal of Advertising Research, vol. 48, no. 4, pp. 484-495.

Sawang, S. (2010), "Sex appeal in advertising: what consumers think", Journal of Promotion Management, vol. 16, no. 1, pp. 167-187.

Sierra, J. J., Hyman, M. R. and Torres, I. M., (2009), "Using a model's apparent ethnicity to influence viewer responses to print ads: a social identity theory perspective", Jounal of Current Issues and Research in Advertising, vol. 31, no. 2, pp. 41-66.

Ueltschy, L. (2011) "Targeting the growing Hispanic market: ethnicity and media preferences", Marketing Management Journal, vol. 21, no. 2, pp. 10-21.

Vagnoni, A. (1999), "Something about this advertising", Advertising Age, vol. 70, no. 6, pp. 30.

Waller, D. S. (1999), "Attitudes towards offensive advertising: an Australian study", Journal of Consumer Marketing, vol. 16, no. 3, pp. 288-294.

Waller, D. S., Deshpande, S. and Erdogan, B. Z. (2013), "Offensiveness of advertising with violent image appeal: A cross-cultural study", Journal of Promotion Management, vol. 19 , no. 4, pp. 400-417.

Wang, C. L. (2008), "Gender differences in responding to sad emotional appeal: a moderated mediation explanation", Journal of Nonprofit \& Public Sector Marketing, vol. 19, no. 1, pp. 55-70.

Wentz, L. (2015), "Welcome to the multicultural mainstream", Advertising Age, vol. 86, no. 6 , pp. 18

Williams, M. (2009), "Close-Up: Does shock advertising still work? Are consumers becoming desensitised to the impact of shocking ads?", Campaign (UK). Available at: http://www.campaignlive.co.uk/article/900778/close-up-does-shock-advertisingwork\#.

Wilson, A. and West, C., (1981), “The Marketing of Unmentionables", Harvard Business Review, vol. 59, no. 1, January/February, pp. 91-102.

Zebrowitz, L. A., Bronstad, P. M. and Lee, H. K., (2007), "The contribution of face familiarity to ingroup favoritism and stereotyping", Social Cognition, vol. 25, no. 2, pp. 306-338.

\section{Appendix 1}

\section{Description of Advert 1:}

Three young males drinking in a pub see some females standing at the bar. The males are discussing whether the females are interested in them when one starts to approach their table. Her expression changes from one of friendliness to horror and at the same time the noise of a car crash is heard. The female is thrown across the room, smashing 
her head against a metal foot rail at the bar. The males also display expressions of shock and have facial injuries. Source:

http://www.youtube.com/watch?v=GX1q66ruuBM\&feature=related

\section{Description of Advert 2:}

A male patient is lying in an intensive care room. The camera pans in on his face as he starts to remember what happened to him. The scene changes to a disco where he is drinking and his girlfriend is trying to dissuade him from doing so. The couple are then seen leaving in a car with the anxious faces of their friends waving them goodbye. The patient then remembers the scene after the car crash with ambulance, medics and them covering the body of his girlfriend who is lying in the road. Source: http://www.youtube.com/watch?v=E51VtAuA_wQ\&feature=related

\section{Description of Advert 3}

The scene starts inside a car on a family outing. The little girl is sitting on the back seat playing with a feather tickling her parents. Soft music is playing and there are affectionate gestures between mother and daughter. Suddenly the father has to brake and the daughter is thrown through the wind screen. The result is not fully shown, only a tuft of hair on the shattered windscreen and a shoe left on the bonnet of the car. The parents have seat belts on and remain unhurt. Source:

http://www.youtube.com/watch?v=DO596QcInEg\&feature=related

\section{Description of Advert 4}

A close-up of a young man driving a motor bike with a girl passenger. The sound of the bike predominates and the boy has to shout above it to talk to his passenger. The scenery behind them is typically Asian. They get behind an old truck and attempt to overtake but find themselves in the path of another truck coming in the opposite direction. The action stops just before the crash. Another Asian person on a bike riding past and a worker in a rice field are also 'frozen'. Both the driver and girlfriend get off the bike to discuss how to avoid the accident. A voiceover says that in real life you don't have time to think about avoiding an accident and the action recommences. The truck ploughs into the motorbike leaving little of the driver or his passenger. However, there is no blood or scenes of carnage. Source:

https://www.youtube.com/watch?v=4Mwl-uE2EzE

\section{Description of Advert 5}

A group of male friends come out of a bar. They have obviously been drinking and walk towards a car parked nearby. Instead of getting into the car, they pick the car up and carry it along the road and through a motorway toll. The voiceover is saying 'When you drink, don't drive'. The advertisement is sponsored by Black Thai whisky and their logo is the last frame in the advertisement. Source:

http://www.youtube.com/watch? $=$ =Xs4KRHBh4nQ\&feature=related 


\section{Description of Ad 6}

A picture of a young beautiful girl is held up to the camera. The hands holding the picture are bandaged. The voiceover (female voice with a Hispanic accent) says, 'My name is Jacqueline Sabarido. This is me before I was hit by a drunk driver. Before the car caught fire. Before my two friends died. Before I had more than 40 operations. When I was just like anyone else in college.' The picture is then removed to reveal a person wearing a hat whose face has been terribly disfigured by fire. The voiceover continues, 'This is me after being hit by a drunk driver'. The final strap line says, 'Don't ever drink and drive'. Source:

http://www.youtube.com/watch?v=qX1Pv2mHPJ0\&feature=related

\section{Description of Ad 7}

A young girl and boy are standing against a wall on a country road. They are gazing into each other's eyes and music is playing 'Can't take my eyes off you'. Suddenly, two cars come along the road. One attempts to overtake the other but then overturns and rolls towards the young couple. The boy is crushed against his girlfriend by the car and immediately dies. The girl is still conscious and screams continuously. Passers-by stare horrified at the accident and passengers in the other car are injured. The scene then switches to clearing the accident - ambulances and medical teams trying to save the victims and the police taking away the driver of the car who caused the accident. The scene changes again to a hospital where the young girl is in theatre to save her life. The parents of the young man are shown his body and the grieving mother breaks down. The next scene shows the driver in court with a short flashback to him speeding down the road, attempting to overtake the car in front but then a cat runs out. He brakes and this causes him to turn his car over and roll towards the young couple. The final scene shows the face of the young woman as she visits her boyfriend's grave. The camera pans out and we see that she is in a wheelchair. The final strap line says, 'The faster the speed, the bigger the mess'. Source:

http://www.youtube.com/watch?v=mEQyfjP-lZM\&feature=related 